\title{
Vitamin B12 Status in Children with Helicobacter pylori Gastritis
}

\author{
Helicobacter pylori Gastriti Tanılı Çocuklarda Vitamin B12 Düzeyi
}

\author{
Hasret Ayyildiz Civan ${ }^{\oplus}$ \\ Bakırköy Dr. Sadi Konuk Training and Research Hospital, Department of Pediatric Gastroenterology, Hepatology and Nutrition, Istanbul, \\ Turkey
}

Received: 20 December 2019 / Accepted: 10 March 2020 / Publication date: 26 June 2020

Cite as: Ayyildiz Civan H. Vitamin B12 status in children with Helicobacter pylori gastritis. Med J Bakirkoy 2020;16(2):120-4.

\begin{abstract}
Objective: Helicobacter pylori is rdescribed as the major etiological factor for gastritis and also associated with gastroesophageal reflux disease, and vitamin $B 12$ deficiencies. Therefore, we aimed to evaluate the relationship between Helicobacter pylori gastritis and vitamin B12 status as well as to determine prevalence of esophagitis in children with H.pylori infections.

Method: A total number of 556 children who underwent eso-gastro-duodenoscopy were evaluated retrospectively. Diagnosis of $H$ pylori infection, esophagitis, and gastritis was performed with histopathologic examination. Patients were divided into H.pylori (+) and (-) groups. Patients' demographic characteristics, physical examination, imaging and laboratory findings were recorded and evaluated.

Results: Patients included in the study consisted of 310 (55.8\%) females, and 246 (44.2\%) males. The mean age was significantly lower in

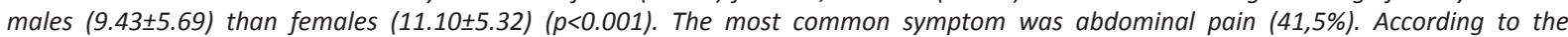
histopathological examination H.pylori was positive in $24.5 \%(n=136)$ of our patients. Of the patients $28.6 \%$ ( $n=159)$ were diagnosed with esophagitis and $55.4 \%(n=308)$ with chronic gastritis. Esophagitis was detected in $30.1 \%$ of patients diagnosed with $\mathrm{H}$.pylori and all chronic gastritis patients were found to be positive for H.pylori ( $p<0.001)$. There were no statistically significant differences found in mean levels of vitamin B12 between H.pylori negative and positive groups of patients with chronic gastritis. But the mean serum levels of vitamin B12 measured in the H.pylori positive group $(382.93 \pm 245.50 \mathrm{pg} / \mathrm{mL})$ was statistically significantly lower than H.pylori-negative group $(467.90 \pm 305.36 \mathrm{pg} / \mathrm{mL})(p=0.028)$. There were also no significant differences found in mean levels of iron between H.pylori-negative and positive groups.

Conclusion: Although all children with chronic gastritis were positive for H.pylori, our findings provide no evidence for a link between esophagitis, iron deficiency and H.pylori infection. In addition, H.pylori infection has been demonstrated to be a risk factor for vitamin B12 deficiency.
\end{abstract}

Keywords: bacterial meningitis, aseptic meningitis, mortality, pediatric intensive care unit

öz

Amaç: Helicobacter pylori gastritin ana etiyolojik faktörü olarak tanımlanmakta, ayrıca gastroözofageal reflü hastalığı ve B12 vitamini eksiklikleri ile de ilişkilendirilmektedir. Bu nedenle, bizde H.pylori gastriti ve B12 vitamin statüsü arasındaki ilişki yanında H.pylori enfeksiyonu olan çocuklarda özofajit prevalansının değerlendirmeyi amaçladık.

Yöntem: Özogastroduodenoskopi yapılan toplam 556 çocuk retrospektif olarak değerlendirildi. H pylori enfeksiyonu, özofajit ve gastrit tanıları histopatolojik inceleme ile konuldu. Hastalar H.pylori pozitif ve negatif gruplara ayrıldı. Hastaların demografik özellikleri, fizik muayene, görüntüleme ve laboratuvar bulguları kaydedildi ve değerlendirildi.

Bulgular: Çalışmaya dahil edilen hastalar 310'u $(\% 55,8)$ kız ve 246 'sı $(\% 44,2)$ erkek idi. Erkek hastalarda ortalama yaş $(9,43 \pm 5,69)$ kızlardan $(11,10 \pm 5,32)$ anlamlı şekilde düşüktü $(p<0,001)$. Hastalarımızda en sık bildirilen semptom karın ağrısıydı $(\% 41,5)$. Histopatolojik incelemeye göre H.pylori hastalarımızın \% 24.5'inde ( $n=136$ ) pozitifti. Hastaların \% 28.6'sı (n=159) özofajit ve \% 55.4'ü ( $n=308$ ) kronik gastrit tanısı aldı. H.pylori tanısı alan hastaların \% 30.1'inde özofajit saptandı ve tüm kronik gastrit hastalarının H.pylori için pozitif olduğu belirlendi ( $p<0,001)$. H.pylori negatif ve pozitif kronik gastritli hasta grupları arasında ortalama B12 vitamini düzeyleri açısından istatistiksel olarak anlamlı bir fark bulunmadı. Ancak H.pylori pozitif grupta $(382,93 \pm 245,50 \mathrm{pg} / \mathrm{mL})$ ölçülen ortalama B12 vitamin düzeyi istatistiksel olarak anlamlı şekilde H.pylori negatif gruptan $(467,90 \pm 305,36 \mathrm{pg} / \mathrm{mL})$ düşük olduğu belirlendi $(p=0,028)$. Bununla beraber H.pylori negatif ve pozitif gruplar arasında ortalama demir düzeyleri açısıdan anlamlı bir fark bulunmadı.

Sonuç: Her ne kadar kronik gastritli tüm çocuklar H.pylori için pozitif olsa da, çalışmamızda H.pylori enfeksiyonu ile özofajit ve demir eksikliği arasında iliş̧ki kurulamamıştır. Bunlara ek olarak, H.pylori enfeksiyonunun B12 vitamini eksikliği için bir risk faktörü olduğu gösterilmiştir.

Anahtar kelimeler: Helicobacter pylori, gastrit, Vitamin B12, özofajit

Corresponding Author:

H. Ayyildiz Civan 0000-0002-5604-9722

hasretayyildiz@yahoo.com

(c) Telif hakkı Sağlık Bilimleri Üniversitesi Bakırköy Dr. Sadi Konuk Eğitim ve Araştırma Hastanesi'ne aittir. Logos Tıp Yayıncılık tarafindan yayınlanmaktadır. Bu dergide yayınlanan bütün makaleler Creative Commons Attf-GayriTicari 4.0 Uluslararası Lisansı ile lisanslanmışttr.

(c) Copyright Health Sciences University Bakırköy Sadi Konuk Training and Research Hospital. This journal published by Logos Medical Publishing.

Licenced by Creative Commons Attribution-NonCommercial 4.0 International (CC BY-NC 4.0) 


\section{INTRODUCTION}

H.pylori is a spiral-shaped, microaerophilic, noninvasive and gram-negative bacteria that colonize gastric epithelial cells with facilitation of flagellumassociated proteins, adhesins, and chemotactic activities ${ }^{(1)}$. It is the most common chronic bacterial infection worldwide particularly in developing countries $(75-90 \%)^{(2)}$. H.pylori infection is generally acquired in early infancy particularly before the age of 10 years and persists throughout entire life without treatment ${ }^{(3)}$. The colonization of bacteria in stomach triggers gastric inflammation. Production of heat shock protein, urease and antigen presented by bacteria lead to activation of T-cells and increase in the levels of certain proinflammatory cytokines which results in gastric mucosal damage ${ }^{(4)}$. Thus, local and systemic immune responses of the host against H.pylori is related with chronic gastritis, peptic ulcer, mucosa-associated tissue lymphoid lymphoma and gastric cancer ${ }^{(5)}$.

H.pylori is widely accepted as the major etiological factor for gastritis and peptic ulcer ${ }^{(6)}$. Although H.pylori infections are mostly asymptomatic, majority of patients develop acute gastritis which alters into chronic gastritis. In addition, childhood H.pylori infections are frequently associated with antral gastritis ${ }^{(7)}$.

Recently, childhood H.pylori infections have been also associated with other digestive disorders such as gastroesophageal reflux disease. Moreover limited number of published data with controversial results, have indicated the presence of an inversely relation of H.pylori with esophagitis severity $(8,9)$. Besides, Helicobacter pylori gastritis has been linked to malabsorption and has been demonstrated as the potential causative agent of vitamin B12 deficiency in numerous studies ${ }^{(10,11)}$. Therefore, we aimed to evaluate the relationship between Helicobacter pylori gastritis and vitamin B12 status as well as to determine the prevalence of esophagitis in children with H.pylori infections.

\section{MATERIALS and METHODS}

This study was performed with the Institutional Review Board protocol approval date 18/02/2019 and number 2019/13 in Istanbul Dr. Sadi Konuk Training and Research Hospital, Department of Pediatric Gastroenterology, Hepatology and Nutrition, between January 2017 and June 2018. A total number of 556 children, aged between 0-18 years, who underwent eso-gastro-duodenoscopy were evaluated retrospectively. The diagnosis of H.pylori infection, esophagitis, and gastritis was made based on histopathologic examination. Patients were divided into H.pylori (+) and H.pylori (-) groups. Patients' demographic characteristics, physical examination, imaging and laboratory findings were recorded.

Blood cell count analysis was performed using patients' venous blood samples. Haematological parameters were analysed using a hematology analyser (Cell-Dyne 3700, Abbott, Abbott Park, IL, USA). Biochemical analysis was performed with serum samples using electro-chemiluminescence immunoassay on Beckman Coulter Unicel DXI 800 analyzer. Serum vitamin B12 analysis was performed using an immunodiagnostic system (Siemens, Advia Centaur $\mathrm{xp}$, Germany) at a normality level of $220 \mathrm{pg} / \mathrm{ml}$.

\section{Statistical analysis}

All the data were analysed with SPSS (Statistical Package for the Social Sciences) software for Windows (V21.0; IBM, Armonk, NY, USA). Individual and aggregate data were summarized using descriptive statistics including mean, standard deviations, medians (min-max), frequency distributions and percentages. Normality of data distribution was verified by Kolmogorov-Smirnov test. Comparison of the variables with normal distribution was made using Student $\mathrm{t}$ test. For the intergroup comparisons of variables which were not normally distributed, the Mann Whitney and Kruskal Wallis tests were performed. Evaluation of categorical variables was performed using chi-square test. P-Values of $<0.05$ were considered statistically significant.

\section{RESULTS}

Patients included in this study consisted of 310 (55.8\%) females, and 246 (44.2\%) males. Mean age of all patients $(n=556)$ was $10.22 \pm 4.87$ months (range: 0-18 years). In addition, the mean age was significantly lower in male patients $(9.43 \pm 5.69)$ than 
Table 1. Comparison of hronic gastritis and esophagitis rates in patients with H.pylori.

\begin{tabular}{|c|c|c|c|c|}
\hline & Clinical Variables & $\begin{array}{c}\text { H.pylori Negative } \\
\text { n (\%) }\end{array}$ & $\begin{array}{c}\text { H.pylori Positive } \\
\text { n (\%) }\end{array}$ & p-value \\
\hline Esophagitis & $\begin{array}{l}\text { Absent } \\
\text { Present }\end{array}$ & $\begin{array}{l}302(71.9 \%) \\
118(28.1 \%)\end{array}$ & $\begin{array}{l}95(69.9 \%) \\
41(30.1 \%)\end{array}$ & 0.645 \\
\hline Chronic gastritis & $\begin{array}{l}\text { Absent } \\
\text { Present }\end{array}$ & $\begin{array}{l}248(59.6 \%) \\
172(41.0 \%)\end{array}$ & $\begin{array}{c}0(0.0 \%) \\
136(100.0)\end{array}$ & $0.000^{*}$ \\
\hline
\end{tabular}

$*=p<0.05$ statistically significant.

Table 2. Comparison of laboratory findings between H.pylori negative and positive groups in patients diagnosed with chronic gastritis.

\begin{tabular}{lccc} 
Laboratory results & $\begin{array}{c}\text { H.pylori Negative } \\
\text { (Mean } \pm \text { SD) }\end{array}$ & $\begin{array}{c}\text { H.pylori Positive } \\
\text { (Mean } \pm \text { PD) }\end{array}$ & \\
& & P-value & \\
\hline Iron (ug/dL) & $64.83 \pm 48.75$ & $68.62 \pm 35.75$ & 0.230 \\
Hemoglobin (g/dL) & $12.46 \pm 1.32$ & $12.74 \pm 1.54$ & $0.050 *$ \\
MCV (fL) & $85.46 \pm 53.38$ & $80.81 \pm 5.41$ & 0.860 \\
RDW (\%) & $13.64 \pm 1.98$ & $13.52 \pm 1.60$ & 0.848 \\
PLT (x10 $/ \mathrm{L})$ & $303.8 \pm 897.5$ & $332.4 \pm 985.0$ & 0.058 \\
Vitamin B12 $(\mathrm{pg} / \mathrm{mL})$ & $431.7 \pm 263.4$ & $382.9 \pm 245.5$ & 0.171
\end{tabular}

$*=p<0.05$ statistically significant.

female patients $(11.10 \pm 5.32)(p<0.001)$.

The most common symptom reported in our patients was abdominal pain seen in $41.5 \%(n=220)$ of the cases, followed by abdominal pain + nausea ( $n=118,22.3 \%)$, vomiting ( $n=57,10.8 \%)$, and weight loss + sour liquid rushing into the mouth + puffiness + dysphagia ( $n=45,8.5 \%$ ) respectively. According to the histopathological examination H.pylori was positive in $24.5 \%(n=136)$ of our patients. In addition, $28.6 \%(n=159)$ of the patients were histopathologically diagnosed with esophagitis and $55.4 \%(n=308)$ of them with chronic gastritis. In our study, esophagitis was detected in $30.1 \%$ of patients diagnosed with H.pylori-positive and $28.1 \%$ of H.pylori -negative patients $(p=0,645)$. Moreover, all of our patients with chronic gastritis were found to be positive for H.pylori $(p<0,001)$ (Table 1).

According to the evaluation of laboratory findings; the mean values of: iron, hemoglobin, MCV, RDW, vitamin B12 and PLT in the study population were $70.67 \pm 42.40 \mathrm{ug} / \mathrm{dl}, 12.62 \pm 1.39 \mathrm{~g} / \mathrm{dL}, 82.48 \pm 30.85 \mathrm{fL}$, $13.50 \pm 1.75 \%, 448.11 \pm 294.28 \mathrm{pg} / \mathrm{mL}$, and $315.8 \pm 103,8 \times 10^{9} / \mathrm{L}$, respectively. The comparison of laboratory findings between H.pylori -negative and
Table 3. The comparison of laboratory findings between esophagitis- negative and positive groups in H.pylori positive cases.

\begin{tabular}{lccc}
\hline Laboratory results & $\begin{array}{c}\text { Esophagitis } \\
\text { Negative } \\
\text { (Mean } \pm \text { SD) }\end{array}$ & $\begin{array}{c}\text { Esophagitis } \\
\text { Positive } \\
\text { (Mean } \pm \text { SD) }\end{array}$ & P-value \\
\hline Iron (ug/dL) & $66.44 \pm 33.96$ & $73.71 \pm 40.19$ & 0.606 \\
Hemoglobin (g/dL) & $12.54 \pm 1.56$ & $13.19 \pm 1.40$ & 0.121 \\
MCV (fL) & $80.41 \pm 5.39$ & $81.70 \pm 5.45$ & 0.496 \\
RDW (\%) & $13.58 \pm 1.70$ & $13.39 \pm 1.39$ & 0.734 \\
PLT (x10 $/ \mathrm{L})$ & $332.0 \pm 973.0$ & $333.1 \pm 102.8$ & 0.697 \\
Vitamin B12 $(\mathrm{pg} / \mathrm{mL})$ & $389.38 \pm 261.74$ & $361.27 \pm 187.36$ & 0.877 \\
\hline
\end{tabular}

positive groups in patients diagnosed with chronic gastritis is presented in Table 2. Mean level of hemoglobin was found to be statistically higher in H.pylori -positive group $(12,74 \pm 1,54)$ than H.pylori -negative group $(12,46 \pm 1,32)(p=0.05)$. Additionally, there were no statistically significant differences in mean serum levels of iron, MCV, RDW, vitamin B12 and POLITIKA between H.pylori -negative and positive groups $(p>0,05)$ (Table 2$)$.

Furthermore, the comparison of laboratory findings between esophagitis- negative and positive groups in H.pylori -positive cases is presented in Table 3. Any statistically significant differences were found in mean serum levels of iron, hemoglobin, MCV, RDW, vitamin B12 and PLT between esophagitis -negative and positive groups ( $p>0,05)$ (Table 3$)$.

Additionally, only H.pylori- positive and negative cases were compared according to the laboratory findings; the mean serum levels of vitamin B12 measured in the H.pylori -positive group $(382,93 \pm 245,50$ $\mathrm{pg} / \mathrm{mL}$ ) was statistically lower than the H.pylori -negative group $(467,90 \pm 305,36 \mathrm{pg} / \mathrm{mL})(p=0,028)$ (Table 4). 
Table 4. Comparison of laboratory findings according to H.pylori diagnosis.

\begin{tabular}{|c|c|c|c|}
\hline Laboratory results & $\begin{array}{c}\text { H.pylori } \\
\text { Negative } \\
\text { (Mean士SD) }\end{array}$ & $\begin{array}{c}\text { H.pylori } \\
\text { Positive } \\
\text { (Mean士SD) }\end{array}$ & P-value \\
\hline Iron (ug/dL) & $71.28 \pm 44.24$ & $68.62 \pm 35.75$ & 0.996 \\
\hline Hemoglobin (g/dL) & $12.58 \pm 1.34$ & $12.74 \pm 1.54$ & 0.120 \\
\hline $\operatorname{MCV}(f L)$ & $82.94 \pm 34.75$ & $80.81 \pm 5.41$ & 0.929 \\
\hline RDW (\%) & $13.50 \pm 1.79$ & $13.52 \pm 1.60$ & 0.515 \\
\hline PLT $\left(\times 10^{9} / \mathrm{L}\right)$ & $311.1 \pm 104.0$ & $332.4 \pm 985.0$ & 0.064 \\
\hline Vitamin B12 (pg/mL) & $467.90 \pm 305.36$ & $382.93 \pm 245.50$ & $0.028 *$ \\
\hline
\end{tabular}

$*=p<0.05$ statistically significant.

\section{DISCUSSION}

Helicobacter pylori infection is the most common infection worldwide and it is estimated that approximately half of the world's population is infected with Helicobacter pylori. Since majority of the infected patients are asymptomatic, it seems difficult to eradicate H.pylori infection. Moreover, H.pylori is commonly responsible for etiology of gastritis (7). Development of chronic gastritis depends on bacterial virulence factors, host and environmental factors (3). In a meta analysis, Weck et al. concluded that a very strong association existed between H.pylori infection and chronic gastritis by evaluating 66 relevant articles ${ }^{(12)}$. Similarly, Langner et al. reported chronic active gastritis in all children with H.pylori infection in their study investigating 132 gastric biopsies ${ }^{(13)}$. In accordance with these published data, in our study all of our patients with chronic gastritis were found to be positive for H.pylori.

Although a link has been identified between decreased serum iron status and childhood H.pylori infection, it is debated in published data whether H.pylori infection causes iron deficiency or iron deficiency anemia ${ }^{(14)}$. In a study, Vendt et al. found no relationship between H.pylori infection and iron deficiency in 363 children with H.pylori infection ${ }^{(15)}$. In addition, older age is documented to be more responsible for iron deficiency ${ }^{(15,16)}$. Supportively in our study, no statistically significant differences were found between H.pylori -negative and positive groups according to the mean serum iron levels.

It is appears to be controversy in the limited number of published data whether Helicobacter pylori infec- tion is protective or triggering factor for gastroesophageal reflux disease. Prevalence of gastroesophageal reflux disease reported to be increased as a result of decrease in the Helicobacter pylori incidence ${ }^{(9)}$. Daugule et al. reported a higher prevalence of H.pylori in patients with reflux oesophagitis among 130 children ${ }^{(17)}$. Similarly, Moon et al. concluded that Helicobacter pylori infection is a risk factor for reflux oesophagitis development ${ }^{(18)}$. On the contrary, Emiroglu et al. found no significant association between the prevalence of $H$.pylori infection and reflux oesophagitis or the oesophagitis severity in 206 children (19). Supportively, Zagorski et al. compared 308 children with reflux esophagitis and 418 patients with chronic gastritis without reflux esophagitis. Helicobacter pylori infection was detected in $44.5 \%$ of children with reflux esophagitis and it was not significantly differed in patients without reflux esophagitis. Researchers concluded that the development of reflux esophagitis was not associated with Helicobacter pylori infection ${ }^{(9)}$. In accordance with these data, $28.6 \%$ ( $n=159)$ of our patients were histopathologically diagnosed with esophagitis. Esophagitis was detected in $30.1 \%$ of patients diagnosed with H.pylori and $28.1 \%$ in H.pylori negative patients. Thus, Helicobacter pylori infection was not significantly effected prevalence of esophagitis in our study.

Although various conditions may lead to vitamin B12 deficiency, it is frequently caused by chronic gastritis. H.pylori-induced gastritis damages the parietal cells which are essential for vitamin B12 absorption. Kaptan et al. reported Helicobacter pylori infection in $56 \%$ of patients with pernicious anemia. Researchers demonstrated a post-treatment improvement of vitamin $\mathrm{B} 12$ in $40 \%$ of the patients ${ }^{(20)}$. In a study by Sarari et al. which, compared H.pylori -infected and non-infected patients consisting of 60 children, mean levels of vitamin B12 were 207.7+21.9 and $419.7+39.8$, respectively $(p=0,000)$. Vitamin B12 was found to be lower than $200 \mathrm{pg} / \mathrm{ml}$ in $67.4 \%$ of patients with H.pylori infection ${ }^{(21)}$. Similarly, Akcam et al. reported mean levels of vitamin B12 as $303 \pm 135 \mathrm{pg} /$ $\mathrm{mL}$ in Helicobacter pylori positive and $393 \pm 166 \mathrm{pg} /$ $\mathrm{mL}$ Helicobacter pylori -negative groups in a study included 50 children aged 5 -18 years ${ }^{(22)}$. In accordance with these data, the mean serum level of vitamin B12 measured in the H.pylori -positive group 
$(382,93 \pm 245,50 \mathrm{pg} / \mathrm{mL})$ was statistically lower than the H.pylori -negative group $(467,90 \pm 305,36 \mathrm{pg} / \mathrm{mL})$ in present study.

In conclusion, although all children with chronic gastritis were positive for H.pylori, our findings have not provided any evidence for a link between esophagitis, iron deficiency and H.pylori infection. In addition, H.pylori infection has been demonstrated to be a risk factor for vitamin B12 deficiency. In this respect a rapid, accurate diagnosis and an effective treatment approach are crucial to achieve appropriate management of $H$.pylori infection in children.

\section{Acknowledgements}

Author declare that there is no conflict of interest. Any specific grant was not received for this research from funding agencies in the public, commercial, or not-for-profit sectors.

Ethics Committee Approval: This study was performed with the Institutional Review Board protocol approval date 18/02/2019 and number 2019/13 in Istanbul Dr. Sadi Konuk Training and Research Hospital, Department of Pediatric Gastroenterology, Hepatology and Nutrition, between January 2017 and June 2018.

\section{Conflict of Interest: None \\ Funding: None}

Informed Consent: Informed consent was obtained from all individual participants included in the study.

\section{REFERENCES}

1. Windsor HM, O'Rouke J. Bacteriology and taxonomy of Helicobacter pylori. Gastroenterol Clin North Am. 2000;29(3):633-48. https://doi.org/10.1016/\$0889-8553(05)70135-7

2. Paul B, Adimoolam S, Qureshi MJ. A Review of Helicobacter pylori infection diseases, antibiotic resistance and diagnosis. Asian J Pharm Clin Res. 2018;11(12):566-71. https://doi.org/10.22159/ajpcr.2018.v11i12.24745

3. Sýkora J, Rowland M. Helicobacter pylori in pediatrics. Helicobacter. 2011;16:59-64. https://doi.org/10.1111/j.1523-5378.2011.00882.x

4. Testerman TL, Morris J. Beyond the stomach: an updated view of Helicobacter pylori pathogenesis, diagnosis, and treatment. World J Gastroenterol. 2014;20(36):12781-808. https://doi.org/10.3748/wjg.v20.i36.12781

5. McColl KE. Helicobacter pylori infection. N Engl J Med. 2010;362(17):1597-604.

https://doi.org/10.1056/NEJMcp1001110

6. Pacifico L, Anania C, Osborn JF, Ferraro F, Chiesa C. Consequences of Helicobacter pylori infection in children. World J Gastroenterol. 2010;16(41):5181-94. https://doi.org/10.3748/wjg.v16.i41.5181
7. Watari J, Chen N, Amenta PS, Fukui H, Oshima T, Tomita T, et al. Helicobacter pylori associated chronic gastritis, clinical syndromes, precancerous lesions, and pathogenesis of gastric cancer development. World J Gastroenterol. 2014;20(18): 5461-73.

https://doi.org/10.3748/wjg.v20.i18.5461

8. Richter JE. Effect of Helicobacter pylori eradication on the treatment of gastro-oesophageal reflux disease. Gut. 2004;53(2):310-1.

https://doi.org/10.1136/gut.2003.019844

9. Zagorski SE, Nazarenko ON. Reflux esophagitis and Helicobacter pylori: Is there an association in children? Progress in Health Sciences. 2014;4(1):41-6.

10. Nizami MA, Mirza SA, Khan FA. Frequency of Vitamin B12 Deficiency in patients with Helicobacter pylori gastritis. Pak Armed Forces Med J. 2012;62(2):203-5. Available from: https:// www.pafmj.org/index.php/PAFMJ/article/view/1663/1432

11. Kadhim G, Shikh M, Omar H, Ismail A. Vitamin B12 Deficiency in Helicobacter pylori Infected Patients. Open Access Library Journal. 2018;5(3):1-4. https://doi.org/10.4236/oalib.1104172

12. Weck MN, Brenner H. Association of Helicobacter pylori infection with chronic atrophic gastritis: Meta-analyses according to type of disease definition. Int J Cancer. 2008;123(4):874-81. https://doi.org/10.1002/ijc.23539

13. Langner M, Machado RS, Patrício FR, Kawakami E. Evaluation of gastric histology in children and adolescents with Helicobacter pylori gastritis using the Update Sydney System. Arq Gastroenterol. 2009;46(4):328-32. https://doi.org/10.1590/S0004-28032009000400015

14. Ashorn M, Ruuska T, Mäkipernaa A. Helicobacter pylori and iron deficiency anaemia in children. Scand J Gastroenterol. 2001;36(7):701-5. https://doi.org/10.1080/003655201300191950

15. Vendt N, Kool P, Teesalu K, Lillemäe K, Maaroos HI, Oona M. Iron deficiency and Helicobacter pylori infection in children. Acta Paediatr. 2011;100(9):1239-43. https://doi.org/10.1111/j.1651-2227.2011.02281.x

16. Huang SC, Yang YJ, Cheng CN, Chen JS, Lin CH. The etiology and treatment outcome of iron deficiency and iron deficiency anemia in children. J Pediatr Hematol Oncol. 2010;32(4):282-5. https://doi.org/10.1097/MPH.0b013e3181d69b2b

17. Daugule I, Rumba I, Alksnis J, Ejderhamn J. Helicobacter pylori infection among children with gastrointestinal symptoms: a high prevalence of infection among patients with reflux oesophagitis. Acta Paediatr. 2007;96(7):1047-9. https://doi.org/10.1111/j.1651-2227.2007.00329.x

18. Moon A, Solomon A, Beneck D, Cunningham-Rundles S. Positive association between Helicobacter pylori and gastroesophageal reflux disease in children. J Pediatr Gastroenterol Nutr. 2009;49(3):283-8. ttps://doi.org/10.1097/MPG.0b013e31818eb8de

19. Emiroglu HH, Sokucu S, Suoglu OD, Gulluoglu M, Gokce S. Is there a relationship between Helicobacter pylori infection and erosive reflux disease in children?. Acta Paediatr. 2010;99(1):121-5. https://doi.org/10.1111/j.1651-2227.2009.01512.x

20. Kaptan K, Beyan C, Ural AU, Cetin T, Aycu F, Gulsen M, et al. Helicobacter pylori: is it a novel causative agent in Vitamin B12 deficiency? Arch Intern Med. 2000;160(9):1349-53. https://doi.org/10.1001/archinte.160.9.1349

21. Sarari AS, Farraj MA, Hamoudi W, Essawi TA. Helicobacter pylori, a causative agent of vitamin B12 deficiency. J Infect Dev Ctries. 2008;2(5):346-9. https://doi.org/10.3855/jidc.194

22. Akcam M, Ozdem S, Yilmaz A, Gultekin M, Artan R. Serum ferritin, vitamin B 12, folate, and zinc levels in children infected with Helicobacter pylori. Dig Dis Sci. 2007;52(2):405-10. https://doi.org/10.1007/s10620-006-9422-8. 